\title{
Újabb adatok Somogy megye puhatestü (Mollusca) faunájának ismeretéhez
}

\author{
HÉRA ZOLTÁN
}

HÉRA Z:: New data to the Mollusc fauna of Somogy county.

Abstract: 158 species are recorded in the county and 13 of them are protected. In this paper, the new distribution data of 19 species are reported, 6 of which are protected. Theodoxus danubialis (C. Pfeiffer, 1828) was first found in the river Dráva within the past 60 years.

\section{Bevezetés}

2001-ben jelent meg a megyénk állatvilágát bemutató katalógus, amelynek célja az volt, hogy a XX. századi faunisztikai kutatások legfontosabb somogyi vonatkozású eredményeit a Magyar Millennium emlékére közkinccsé tegye. Természetesen egy ilyen kötet sohasem lehet teljes, számos állatcsoportról még nem áll rendelkezésre információ, másrészt az egyes csoportokban megszerzett ismereteink is tovább gyarapodnak, amelynek indukálója a természeti környezetünk szüntelen változása, forrása pedig a kutatások folytatása. Jelen cikk a puhatestűek elterjedésének ismeretéhez (HÉRA \& VARGA, 2001) ad újabb adatokat.

\section{Anyag és módszer}

A Duna-Dráva Nemzeti Park szervezésében 2000-től biomonitoring vizsgálatok folynak a Dráva mentén. 2001-ben a puhatestüek mintavételezése 17 mintavételi ponton került sor Őrtilos és Babócsa között. A mintákból 86 faj 9791 egyede került elő. A fauna általános vizsgálata egyeléses gyüjtéssel, hordalékok és uszadékok molluszkumának elemzésével valósult meg, a faj színtű vizsgálatok a fajtól függően kvadrát módszerrel, hálózással illetve mesterséges búvóhely kihelyezésével és egyeléssel történtek.

Szintén a DDNP megbízásából a Somogy Megyei Múzeum Természettudományi Osztálya szervezésében 2001-ben a Látrányi-puszta Természetvédelmi Terület zoológiai alapfelmérésének részeként malakológiai vizsgálatok is voltak. A talajfelszíni törmelék, uszadék- és iszapmintákból, valamint fühálózással és egyeléssel 65 faj 3248 példánya került meghatározásra.

\section{Újabb eredmények}

A Magyarországon védett puhatestűek közül 11 csiga- és 2 kagylófaj somogyi előfordulásáról van tudomásunk. Fokozottan védett faj nincs közöttük. Különösen örvendetes tény, hogy a Theodoxus danubialis (C. Pfeiffer, 1828) ismét jelen van a Dráva hazai szakaszán. A faj első adata a folyóból Soós (1933) közléséből származik. Ugyanő a Kárpát- 
medence molluszka faunájának ismertetésekor ekként említi a légrádi lelőhelyet: „A $D u$ na jobboldali mellékvizeiben sokkal gyakoribb, igy nevezetesen a Szávában és ennek mellékvizeiben, s bizonyára messzebb elterjedt a Drávában és a Murában is, bár biztos adatunk a Drávából csak Légrádról, a Murából pedig Kakonyáról van (DuDICH)" (Soós, 1943). Légrád őrtilossal átellenben a folyó jobb partján terül el, ma Horvátországhoz tartozik.

A 90-es évek Dráva-kutatása során a faj élő egyedei nem kerültek elő a folyó magyarországi szakaszáról (VARGA, 1995). 1997-ben azonban Drávasztárán egyetlen héj felbukkan az uszadékban (VARGA \& UHERKOVICH, 1998).

A Duna-Dráva Nemzeti Park által koordinált Dráva-biomonitoring vizsgálatok során a puhatestűek monitorozásának egyik mintavételi pontjául az őrtilos vasútállomás melletti partszakaszát választottam. Ez a hely a Mura torkolati pontja, így a bal parton még több kilométer hosszan a Mura vize áramlik a Drávában. 2001. X. 31-én a Dráva rendkívül alacsony vízállása mellett a kikötő védőkövezésén mintegy 1000 példány volt megfigyelhető, 150-200 egyed/m² sürüséggel! Az állatok között adult és juvenilis egyedek is előfordultak, többségükben feketén bekérgezett héjjal.

Mivel a mintavételi ponton az év során teleszkópos nyélre szerelt hálóval nem sikerült egyetlen példányt sem fellelnem ebből a vízmélységből, így felmerül a gyanú, hogy a populáció friss megtelepedését sikerült kimutatni. Ezt látszik alátámasztani az a tény is, hogy 2002. I. 01-én egyetlen állat sem volt megfigyelhető ugyanitt, pedig a vízállás továbbra is szokatlanul alacsony volt, míg 2001. I. 25-én itt ismét nem, ám 200 méterrel lejjebb a partvédő kövezésen ismét jelen volt a faj. Az alacsony vízállásnak köszönhetően a kövezés és a meder egyes pontjai szárazra kerültek, így a fagyos aljzaton milliószámra feketéllő, felnyílt Dreissena polymorpha (Pallas, 1771) héjak között frissen elpusztult, ET1 létállapotú (DomoKos, 1995) Theodoxus danubialis, Psedanodonta complanata (Rossmässler, 1835), valamint Amphimelania holandri (Pfeiffer, 1828) egyedeket sikerült begyüjteni. Utóbbiak szintén védett fajok. Megjegyzendő körülmény, hogy e csigafajok héjai morfológiai okok miatt csak ritkán találhatók meg az uszadékokban, az élő állatok pedig nagy erővel tapadnak a szilárd aljzathoz, így a hálóhúzással való gyüjtés sem feltétlenül sikeres.

Az Amphimelania holandri ez idáig csak Bélavár - Bolhó térségéből volt ismert, így őrtilosi felbukkanása új adat, s bár koránt sem meglepő, de örvendetes tény amiatt, hogy az esetleg megépítésre kerülő Novo Virje-i erőmű tervezett vízduzzasztása feletti ponton él, így itteni állománya kevésbé veszélyeztetett, mint a Vízvár térségében élő, jóval nagyobb populációi.

1. táblázat: A kagylófajok megoszlása a vízvári Dráva-hordalékban

\begin{tabular}{|c|l|c|c|c|c|}
\hline \multirow{2}{*}{ Sorszám Kagylófajok } & \multicolumn{3}{c|}{ héjszám = egyedszám } & \multirow{2}{*}{ gyakoriság } \\
\cline { 3 - 5 } & & adult & juvenilis & összesen & gya \\
\hline 1. & Dreissena polymorpha (Pallas, 1771) & 517 & 319 & 836 & 83,8 \\
\hline 2. & Anodontaanatina (Linnaeus, 1758) & 10 & 7 & 17 & 1,7 \\
\hline 3. & Anodontacygnea (Linnaeus, 1758) & 8 & 2 & 10 & 1 \\
\hline 4. & Pseudanodontacomplanata (Rossmässler, 1835 & 3 & 5 & 8 & 0,8 \\
\hline 5. & Unio crassus Philipsson, 1788 & 1 & 0 & 1 & 0,1 \\
\hline 6. & Uniopictorum (Linnaeus, 1758) & 25 & 57 & 82 & 8,2 \\
\hline 7. & Unio tumidus Philipsson, 1788 & 2 & 0 & 2 & 0,2 \\
\hline 8. & Pisidiumcasertanum (Poli, 1791) & 2 & 0 & 2 & 0,2 \\
\hline 9. & Sphaeriumcorneum (Linnaeus, 1758) & 2 & 1 & 3 & 0,3 \\
\hline 10. & Sphaeriumrivicola (Lamarck, 1818) & 8 & 29 & 37 & 3,7 \\
\hline & Osszesen: & $\mathbf{5 7 8}$ & $\mathbf{4 2 0}$ & $\mathbf{9 9 8}$ & $\mathbf{1 0 0}$ \\
\hline
\end{tabular}




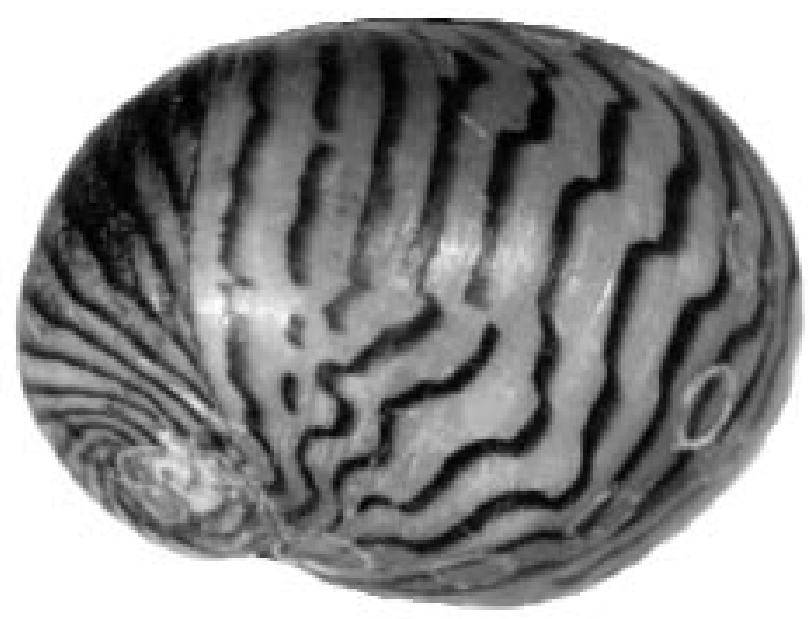

1. ábra: Theodoxus danubialis (C. Pfeiffer, 1828)

Bár a Psedanodonta complanata drávai elterjedéséről is kevés adat áll rendelkezésre, Soós zákányi előfordulásáról már tudósított (Soós, 1943). A faj ritkaságát jól mutatja a Vízváron, a kikötő árterén lerakódott hordalékból 2001. III. 17-én gyüjtött $10 \mathrm{dm}^{3}$ hordalékminta kagylóinak fajspektruma (1. táblázat).

Az anyagban szereplő, szintén védett Unio crassus Philipsson, 1788 vízvári adata egyúttal a folyóbeli előfordulását elsőként igazoló adat, mert az állat jelenlétét a térségben eddig csak a Rinyából és a Dombó-csatornából tudhattuk biztosan (VARGA \& UhERKOVICH). Az előkerült héj teljes, friss, kis területen byssusfonalak borítják. Megjegyzendő körülmény, hogy valamennyi nagytestü kagylófaj teknőjén látható a Dreissena polymorpha megtelepülésének nyoma, ami mutatja a faj erős drávai invázióját. Térhódításáról elsőként VARGA \& UHERKOVICH (1998) számolt be.

Ugyancsak a drávai biomonitoring vizsgálatokkal összefüggésben került elő Zákány falu felső temetőjében 2001. VI. 17-én a védett Cepaea hortensis (Müller, 1774) egy izolált populációja. Az állomány nagysága mintegy 500 egyed, egyszínű és csíkozott héjú génváltozatai egyaránt jelen vannak. Mivel a temetőt 3 oldalról mezőgazdasági területek határolják, bejárata felől pedig rendszeresen nyírt gyep húzódik, természetes szétterjedése kevéssé valószínű. Behurcolása minden bizonnyal növényi anyagokkal történt, ezek közvetítésével magánkertekbe és más parkosított élőhelyekre is átkerülhet. 20 kilométeres körzetben egyetlen más temetőben sem volt fellelhető.

Ez a faj Kaposváron már 1993-ban felbukkant, sikeres megtelepülését jelzi, hogy a város egymástól távol eső pontjain is rendszeresen szem elé kerül. Így például nagyobb populációja él a Gárdonyi Géza általános iskola kerítése mentén ültetett növényzetben, a Baross Gábor utca 14-16. alatti kereskedelmi lerakat területén és a Városi Sportcsarnok déli kerítésén belüli cserjésben. Ez utóbbi lelőhelyén együtt fordul elő a szintén védett Cepaea nemoralis (Linnaeus, 1758) egyedeivel. Mindkét faj behurcolás révén került erre az élőhelyre. Utóbbi faj egy Kaposvárhoz közeli élőhelyen, a Húskombinát horgásztavaként emlegetett mesterséges tó déli felén, a kifolyó melletti füzes, bodzás területen is megtelepült. A behurcolást bizonyítja az Arianta arbustorum (Linnaeus, 1758) jelenléte is. A patak melletti növényzet egészen a Kapos-folyóig húzódik, így e fajok szétterjedésére lehetőség van. A tó értékes faja a Musculium lacustre (Müller, 1774), amely a kifolyó előtti mederszakaszon nagy számban él. 
Tovább tart a Potamopyrgus antipodarum (Gray, 1843) vizicsiga invázív terjeszkedése. 1999-ben megjelent a Külső-Somogy területéről a Balatonba futó Tetves-patak mellékágában a Látrányi-puszta Természetvédelmi Területen, 2001. III. 16-án üres héjait találtam a gyékényesi Kavicsbánya-tó strandjának fövenyén képződött lakusztrikus üledékben (DOMONKOS \& VARGA, 1994).

Az Arion lusitanicus Mabille, 1868 ugyancsak terjed Külső-Somogy településein. Bár a fajt herbivor kártevőként tartjuk számon, alkalmam volt megfigyelni a kerékpárúton elgázolt fajtársának kannibalizmusát illetve kutyaürülék fogyasztását.

A Tandonia budapestensis (Hazay, 1881) újabb Dráva-menti lelőhelye a zákányi alsó (telepi) temető. 2001.X. 31-én komposzthalom szilárd részei alatt 4 adult egyed volt megfigyelhető, egy példánya begyüjtésre került. A faj jelenléte Csurgó térségében 1972 óta ismert (KovÁCS, 1972).

A cikkben hivatkozott példányok a Somogy Megyei Múzeum Természettudományi Osztálya gyüjteményében kerültek elhelyezésre.

\section{Irodalom}

Domokos T. 1995: A Gastropodák létállapotáról, a létállapotok osztályozása a fenomenológia szintjén Malakológiai Tájékoztató 14: 79-82.

Domokos T. - VARGA A. 1994: Az uszadékokról, különös tekintettel a Drávából származó uszadék molluszka tartalmának vizsgálatáról - Malakológiai Tájékoztató 13: 67-79.

HÉra Z. - VArga A. 2001: Somogy megye puhatestü (Mollusca) faunája - Natura Somogyiensis 1: 29-40. KovÁCs Gy. 1972: Somogy-Csurgó és környékének Mollusca faunája - Állattani Közlemények, 59: 86-94. Soós L. 1933: Malakofaunisztikai adatok a Dunántúlról - Állattani Közlemények 30: 12-26.

Soós L. 1943: A Kárpát-medence Mollusca faunája - Budapest: pp 21.

VARga A. 1995: A Dráva menti puhatestű Mollusca fauna kutatásának eddigi eredményei - Dunántúli Dolg. Term. Tud. Sor. 8: 9-21.

VARGa A. - Uherkovich Á. 1998: A Dráva menti puhatestű (Mollusca) fauna kutatásának újabb eredményei Dunántúli Dolg. Term. tud. Sorozat 9: 43-68.

\section{New data to the Mollusc fauna of Somogy county}

\section{ZOLTÁN HÉRA}

Theodoxus danubialis (C.Pfeiffer, 1828), Psedanodonta complanata (Rossmassler, 1835), Unio crassus Philipsson, 1788, and Amphimelania holandri (Pfeiffer,1828) were found in new collecting sites in the river Dráva. In the vicinity of Kaposvár, two species, Cepaea hortensis (Müller, 1774) and Cepaea nemoralis (Linnaeus, 1758) were introduced. New data are reported about the spread of three invasive species along the river Dráva and in the Outer Somogy.

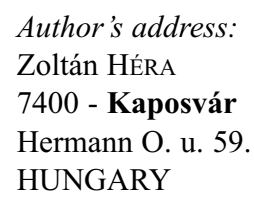

